\title{
FDI flows and reinvested earnings: statistical measurement, perceptions and economic interpretation*
}

\section{Gábor Oblath}

Senior Research Fellow Institute of Economics, Centre for Economic and Regional Studies, Hungarian Academy of Sciences:

Scientific Advisor Kopint-Tárki Institute for Economic Research E-mail: oblath.gabor@krtk.mta.hu
Using Hungarian data for the period 2008-2014 as an example, the study examines the effects of two internationally endorsed methodological revisions affecting the interpretation and quantification of RE (reinvested earnings). The empirical importance of the revision introduced in 2008 is attested by the fact that while the present methodology indicates a net FDI (foreign direct investment) inflow of 10.5 billion euros, the one applied until 2007 would suggest a cumulative net outflow of 5.6 billion euros from Hungary in the period 2008-2014. The huge difference between the two is hidden in statistics on the IIP (international investment position) of the country, which is beyond the focus of most analysts. Although the revisions resulted in the congruence of statistical data with economic concepts of FDI income and RE, they may have become less expressive of the decisions and behaviour of foreign investors. In addition, the revisions lead to breaks in national time series and raise questions regarding comparability of data across countries. For comparisons over time and between countries, the author recommends data on changes in (net) FDI stocks, unaffected by the methodological revisions.

KEYWORDS:

FDI flows and stocks.

Reinvested earnings.

Methodological revisions.

DOI: $10.20311 /$ stat2017.K21.en048

* The research underlying this article was supported by the National Research, Development and Innovation Office (Project No. 124808-K). The author acknowledges the helpful comments of Antónia Hüttl and Paul Marer on earlier versions of the study. Any remaining errors are those of the author. 


\begin{abstract}
Although our study relies on Hungarian statistical data on FDI (foreign direct investments), its focus is on conceptual and methodological issues related to the measurement of FDI flows ${ }^{1}$ and their components, rather than on actual developments in Hungary. This partly explains why our empirical investigation covers the period 2008-2014 and only hints upon changes in 2015-16. ${ }^{2}$ Actually, we consider Hungary's case as an example for demonstrating the effects of two important, internationally endorsed/required methodological revisions concerning the statistical interpretation and measurement of FDI income on the one hand, and dividends, on the other. ${ }^{3}$ Both affect the quantification of RE (reinvested earnings), which (besides equity capital and debt instruments) is one of the components of FDI flows.

Given that empirical experiences with methodological revisions are in the focus of our study, an important point needs clarification at the outset: why do we not extend the analysis of the impact of these revisions beyond Hungary and add observations on other countries as well? It would be most instructive to do so, but this is not actually feasible. In spite of extended search, we have found no other country disclosing information on the quantitative effects of the two revisions. It has to be stressed therefore that this study could not have been prepared without the courtesy of the statisticians of the MNB (Magyar Nemzeti Bank, the Central Bank of Hungary). Since the inception of the two methodological revisions, the data on adjustments connecting the former and the present methodology have been published together with the final FDI figures for the previous year. ${ }^{4}$ This essential information is undisclosed by statistical departments of other central banks.

In view of the fact that most of the statistical agencies in charge of FDI data are much less open regarding the effects of the revisions than the respective Hungarian agency, it is important to state in advance that the difficulties concerning the comparability of, and paradoxes related to the interpretation of FDI statistics preceding and following the introduction of the revisions is likely to apply to several other, if not all, countries having implemented these revisions. The only difference is that while in Hungary's case the problems of comparison and interpretation can be identified and quantified, no similar possibility exists for other countries.

\footnotetext{
${ }^{1}$ In this article, we use the terms "flows" and "transactions" in the same sense.

${ }^{2}$ The other part of the explanation is that two extraordinarily large individual transactions had a powerful impact on Hungary's FDI flows in 2015 and 2016, and the details of these transactions are beyond the scope of this study.

${ }^{3}$ The corresponding methodological standards are described in the BPM6 (Sixth Edition of the Balance of Payments and International Investment Position Manual) of the IMF (International Monetary Fund) (IMF [2009]) and in BD4 (the OECD [Organisation for Economic Co-operation and Development] Benchmark Definition of Foreign Direct Investment) (OECD [2008]).

${ }^{4}$ See $M N B$ [2014b], [2015a], [2016], [2017b].
} 
The rest of the study is structured as follows. First, we discuss the background and motivations of the analysis, highlighting the main issues to be addressed. Second, the relevant statistical concepts are defined and the details of the methodological revisions are explained. Third, we illustrate the effects of the revisions on FDI profits, reinvested earnings and FDI flows by numerical examples, and show the empirical importance of the revisions relying on Hungarian FDI data. The final section draws conclusions and formulates recommendations for both statisticians and economic analysts.

\section{Background, motivations, paradoxes and issues}

Analysts, when studying FDI flows to emerging economies, tend to monitor not only the size of gross or net flows but also their composition. An increase in "fresh" inflows ${ }^{5}$ is generally regarded as an improving capacity of a country to attract new investments. A rise in RE, in turn, is generally considered a sign of an increase in the capacity to keep foreign investors in the country. Both of these developments are regarded as success indications of an economy and/or a country's economic policy. The methodological revisions addressed in our study, however, have led to important changes in the empirical content of these indicators, which requires caution in their interpretation and, in particular, in their comparison across countries and between years preceding and following the revisions. The necessary caution is rarely exercised by economic analysts, the less so, as relatively few of them are aware of the very existence of the changes. An important motivation of our study is to draw attention to the fact that the actual meaning of certain data may be quite different from what the users of the respective statistics perceive it to be.

Although the details of the two methodological revisions will be elaborated in the next sections, it is worth summarising their essence. As a result of the first revision (applied in Hungary since 2008), the so-called "non-operational" components of after-tax profits/losses (e.g. capital gains/losses and write-offs) were deducted from business accounts in order to reach an indicator corresponding to the COPC ("current operating performance concept") of profits. Since prior to 2008 these items were included in FDI income, this methodological revision resulted in a break in the times series for FDI income, RE, total FDI flows, as well as the balance of the current and financial account of the $\mathrm{BoP}$ (balance of payments).

The second revision, introduced in 2013, involved the deduction of extraordinary dividends, called SUD ("superdividends"), from total dividends; the subtracted items

\footnotetext{
${ }^{5}$ As explained later, by "fresh" capital we mean the sum of equity investments and intercompany loans (the latter are referred to as "debt instruments" in FDI statistics).
} 
are accounted as withdrawals of equity in the financial account of the BoP. The implementation of this revision caused a brake in Hungary's time series for dividends, RE and capital flows from 2013.

The resulting breaks in time series for several important flow indicators are additional motivations for studying the background and implications of the methodological revisions. Further motivations relate to the empirical importance of the revisions and to some broader issues.

The empirical relevance of the subject can be demonstrated by two apparent paradoxes. The first concerns the gap between cumulative flows and changes in stocks: in spite of the fact that during 2008 and 2014 there was a net FDI inflow of 10.5 billion euros to Hungary, the net stock of FDI decreased by 1.2 billion. How could net FDI liabilities fall, if there was a significant positive net inflow? Moreover, not less importantly, where can the huge difference between the two ( 11.7 billion) be recovered?

The other (apparent) paradox concerns the comparison of alternative indications of RE. While, according to business accounts, dividends of FDI companies exceeded their after-tax profits by 11 billion euros (indicating a withdrawal of resources through this channel), BoP statistics report RE amounting to 8.5 billion for the period 2008-2014. What lies behind the huge cumulative difference (19.5 billion)? How at all can RE be positive if the difference between aggregate business profits and dividends is negative?

As the reader might already suspect, the explanation of these apparent and interrelated paradoxes lies in the methodological revisions, as a result of which the cumulative net FDI flows to Hungary display an inflow of 10.5 billion, rather than an outflow of 5.6 billion (suggested by the former methodology) between 2008 and 2014 . The key to solving the apparent quantitative paradoxes - to finding the "missing money" - is in observing the details of the IIP (international investment position) of the country. Every cent "missing" from the BoP (the flow accounts), can be recovered among the items reflecting valuation and other volume changes recorded in the IIP. This observation leads to the fundamental motivations of our study.

We do not wish to question either the intention behind the methodological revisions, or the fact that the revisions resulted in a congruence of the statistical data with the corresponding economic concepts ("income" and RE). The question is whether this conceptual congruence has also led to an increase in the clarity and practical relevance of the data from the point of view of the users of FDI statistics. As to be explained, we are sceptical on the latter point.

To take Hungary's example, if upgraded FDI statistics indicate that RE had a positive sign (and has even been increasing), policy-makers and most analysts are likely to perceive that - at least, with respect to keeping investors in the country - things are on the right track. However, the revised official data conceal the fact that foreign investors have actually withdrawn resources from their companies by collectively deciding on dividends significantly in excess of after-tax profits. We argue that this 
information is at least as relevant for understanding actual developments as the data in BoP statistics. This is why economic analysts would gain a lot if other countries followed the transparent practice of the MNB.

A further, closely related conceptual motivation of the study is to make up for an omission of international agencies promoting, and national agencies implementing, the aforementioned methodological revisions. To our knowledge, no serious attempt has been made as yet on the part of those agencies to call the attention of the users of FDI statistics to an important fact. Namely, the items removed from business accounts (e.g. revaluation losses, write-offs) for the purposes of assembling BoP statistics are by no means "inferior" to the adjusted items appearing in the BoP. Both are equally relevant for understanding changes in net worth, but while some of this information is "revealed" in the BoP, others need to be retrieved from the IIP data.

To use a metaphor: items that have a significant bearing on both changes in the net worth of foreign companies, and changes in aggregate FDI stocks, have been removed from the "shop window" (the BoP) into the "warehouse" (the IIP) of FDI statistics. While statistics on FDI flows are closely monitored by analysts, insufficient attention is being paid to other factors affecting changes in stocks. We wish to draw attention to the macroeconomic relevance of the reallocated items and to the general importance of the IIP, which, to repeat, is the indispensable "warehouse", and not the "dustbin" of FDI statistics.

\section{Concepts and revisions}

In this section, we first clarify the main concepts related to FDI flows and stocks, as well as their interrelationships. Next, the contents of the methodological revisions are discussed, followed by a demonstration of their effects on statistical data by numerical examples. The examples are meant to illustrate the difficulties related to the comparison and interpretation of data before and after the revisions.

\subsection{Basic concepts and the nature of the methodological revisions}

Three concepts need clarification: 1. RE, i.e. the reinvested portion of FDI income (profits) ${ }^{6} ; 2$. FDI flows (transactions) that include RE; 3. the change in FDI stocks which contain FDI flows. The following formulae provide the definitions of the three concepts.

\footnotetext{
${ }^{6}$ Total FDI income includes interest income after intercompany loans as well, but RE is a part of income (profits) from equity investment.
} 
Items recorded in the current account of the BoP:

$$
\mathrm{RE}=\text { FDI profits }- \text { dividends }
$$

Items recorded in the financial account of the BoP:

FDI transactions $=$ RE + FDI equity investments + FDI debt instruments or

$$
\text { FDI transactions }=\text { RE + "fresh" FDI capital. }
$$

Items recorded in the IIP of the country:

$$
\begin{aligned}
\Delta \text { FDI stocks (change in stocks) } & =\text { FDI transactions }+ \text { revaluations }+ \\
& + \text { other volume changes. }
\end{aligned}
$$

Since formula /1/ is an accounting identity, it could also be written to indicate that the FDI profits are the sum of RE and dividends. Why RE is on the left-hand side of the expression is explained by the fact that it is a residual item on which no direct statistical information is available. ${ }^{7}$ This entails that methodological revisions affecting the interpretation and measurement of FDI profits and/or dividends necessarily affect the content (and the value) of RE as well.

Formula /2/ shows the three main components of FDI flows (transactions) accounted in the financial account of the BoP. Besides RE (defined above) and "fresh" equity investments, FDI flows also include debt instruments (formerly referred to as intercompany loans). In order to simplify the discussion, for the purposes of the present analysis, we combine equity investments and debt instruments and refer to their balance as "fresh" FDI capital. ${ }^{8}$ This helps in focusing on the main differences between $\mathrm{RE}$ on the one hand, and the combined effect of the other two items, on the other.

Finally, formula /3/ shows the components of changes in FDI stocks, accounted in the IIP. The latter consist of FDI flows (items discussed in the previous paragraph), as well as valuation effects (changes in the value of FDI stocks due to price and exchange rate changes) and so-called "other volume changes" (e.g. write-off of bad debts, effects of natural disasters, etc.). In our following discussion, we shall address the net effect of the latter two items under the label "valuation effects".

\footnotetext{
${ }^{7}$ Actually, the empirical concept of RE is a "hybrid" construct. FDI profits are accounted for the year when they accrue, while dividends are accounted for the year in which shareholders take the decision, i.e. in the year following the accrual of the profits. Therefore, RE accounted for 2016 is the difference between profits in 2016 and dividends from profits in 2015

${ }^{8}$ Hungary's experience indicates that no clear dividing line exists between equity investments and debt instruments, the two can easily be interchanged with the other. This is why we combine the two into "fresh" capital, as distinct from RE.
} 


\section{The content and nature of the revisions}

The methodological revisions in the focus of this study have affected items on the right-hand side of formula /1/, namely FDI profits and dividends.

Until 2007, the empirical interpretation of formula /1/ was the following in Hungary:

$$
\text { RE (a) = After-tax profits }- \text { dividends reported. }
$$

The methodology for quantifying RE in Hungary until 2007 was based on the socalled AIC (all-inclusive concept) of FDI income. This practically meant that FDI profits recorded in the BoP corresponded to the macroeconomic aggregate of aftertax profits in the business accounts of FDI companies. Accounted dividends, in turn, corresponded to the aggregate of decisions made by shareholders. The difference between the two (formula /1a/) was recorded as RE in the BoP.

Beginning 2008, the methodological revision introduced in Hungary involved the empirical redefinition of FDI profits as follows:

$$
\begin{aligned}
\mathrm{RE}(\mathrm{b}) & =(\text { After-tax profits }- \text { non-operational earnings/losses })- \\
& \text { - dividends reported. }
\end{aligned}
$$

The above definition of FDI profits and RE is based on the COPC. This practically means that only that part of after-tax profits is to be recorded in the BoP as actual FDI income, which does not include revaluation effects and other volume changes. ${ }^{9}$ Therefore, as shown by formula $/ 1 \mathrm{~b} /$, the latter items, i.e. "non-operational" earnings (or losses), are to be deducted from after-tax profits (or losses) as measured by business accounts. ${ }^{10}$ The term in brackets, referred to as "adjusted FDI income" is displayed in the current account of the BoP, while the deducted items are accounted as revaluation effects and other volume changes in the IIP.

The second methodological change, effective in Hungary since 2013, has influenced the content and the size of RE via the empirical redefinition of dividends.

\footnotetext{
${ }^{9}$ As elaborated in Paragraph 11.44 of the BPM6: "Reinvested earnings are [...] linked to the concept of operational earnings generated from production, lending and borrowing financial assets, and renting natural resources, and current transfers. Reinvested earnings do not include any realized or unrealized holding gains or losses. Holding gains and losses may arise from valuation changes, including exchange-rate-related gains and losses, revaluation of fixed assets, and changes in market prices of financial assets and liabilities. Reinvested earnings also do not include gains or losses due to other changes in volume of assets, such as write-offs... and uncompensated seizures of assets. Because business accounting measures of profits often include holding gains or losses, adjustments to business accounting records may be necessary." (IMF [2009] p. 190.)

${ }^{10}$ Statisticians discriminate between operational and non-operational earnings (losses) on the basis of returned questionnaires sent to FDI companies. The respective information is available since 2008.
} 

$\begin{aligned} \mathrm{RE}(\mathrm{c}) & =(\text { After-tax profits }- \text { non-operational earnings/losses })- \\ & -(\text { dividends reported }- \text { SUD })\end{aligned}$

The term in the first bracket is the same as in formula $/ 1 \mathrm{~b} /$, the difference concerns the term in the second bracket. In Hungarian statistics, beginning 2013, SUD (i.e. "exceptional" or "excessive") payments made to shareholders are deducted from dividends reported by FDI companies and accounted as withdrawals of equity (capital outflow) in the financial account of the BoP.

However, the empirical interpretation of the terms exceptional/excessive is far from being straightforward, and the guidance provided by the BPM6 is by no means unambiguous. ${ }^{11}$ National statisticians are largely left on their own to decide the practical interpretation/implementation of the adjustment for SUD. In the interpretation of the MNB ([2014a] p. 11.), "Superdividends are dividends paid out from an enterprise's retained earnings, or dividends exceeding the adjusted profit after tax." 12 The latter part of the definition appears to be somewhat stricter than what seems to be suggested by the (vague) guidelines of the BPM6: “...no attempt is made to align dividend payments with earnings except when the dividends are disproportionately large." (IMF [2009] p. 188.) Since statistical divisions of other central banks have not disclosed their own practical definition of SUD, it is impossible to decide whether Hungary's practice is indeed stricter than that of other countries. We will return to this point when discussing problems of international comparability of the data.

\section{Implications and explanations}

The first methodological revision affects the measurement of FDI income, the second influences the quantification of dividends, but, of course, both affects data on RE and FDI flows (see formula /2/) as well as items accounted in the IIP (see formula /3/).

\footnotetext{
${ }^{11}$ Paragraph 11.27 of the BPM6 states: "Exceptional payments by corporations... to their shareholders that are made out of accumulated reserves or sales of assets should not be treated as dividends. Such exceptional payments, sometimes called superdividends, are treated as withdrawals of equity, and therefore recorded in the financial account... The exceptional nature of the payments is normally determined as being disproportionately large relative to the recent level of dividends and earnings. Although dividends are notionally paid out of the current period's operating surplus, corporations often smooth the payments of dividends, sometimes paying out rather less than operating surplus but other times paying out a little more, especially when the operating surplus itself is very low. For practical reasons, no attempt is made to align dividend payments with earnings except when the dividends are disproportionately large. If the level of dividends declared is greatly in excess of previous dividends and trends in earnings, the excess should be excluded from dividends and shown as a withdrawal of equity..." (IMF [2009] p. 188.) (Italics added by the author.) The practical interpretation of the terms "disproportionately large" and "greatly in excess of" is left to national statisticians.

${ }^{12}$ The expression "adjusted profit after tax" corresponds to the term in the first bracket of formula /1c/.
} 
In the following, we compare the empirical content of some key indicators before and after the methodological revisions. In order to bring this comparison closer to actual developments in Hungary, we draw attention to the fact that since the introduction of the first methodological revision the balance on "non-operational" items was, with the exception of a single year (2015), always negative. Thus, the deduction of these items from after-tax business profits generally involved a higher level of FDI income and RE than what would have been the case before the revisions. In addition, since the introduction of the second revision, the adjustments for SUD were rather significant, therefore, the level of RE was higher, and the level of equity investment was lower than what would have been the case before the revisions.

As a result of the first revision, the size and composition of total FDI flows change. The larger the adjustment for non-operational items (to be referred to as COPC adjustment), the more the size of FDI flows (and the share of RE) increases. The change in the stock of FDI is not, but its composition is affected by the size of the COPC adjustment. The share of revaluation effects (and other volume changes) increases the more, the larger the size of the adjustment. Viewed from another angle: the larger the size of the COPC adjustment, the smaller is the part of the change in FDI stocks attributable to FDI flows.

The second revision (SUD adjustment) does not affect the size of FDI flows, but changes their composition: RE increases and "fresh" inflows decrease. By observing only the methodologically revised data, one may get the false impression that the economy's "capacity to attract" new investments has declined simultaneously with an increase in its "capacity to keep" foreign investors. In contrast with this perception, nothing actually happened, except for the reallocation of SUD from the current account to the financial account of the BoP. Since, as mentioned, the guidelines regarding the empirical definition of SUD are not sufficiently clear (space is left to the reading of national statisticians), the second methodological revision may have resulted in a reduced cross-country comparability of data on RE and "fresh" FDI inflows.

What are the explanations for the methodological revisions reviewed in the foregoing? The most important one is that after-tax profits, as interpreted by corporate accounts, include items that are not considered as components of income in economic (and statistical) terms. In particular, capital gains and losses (e.g. due to revaluation effects) certainly affect the net worth of companies, but they do not represent income. Similarly, dividends significantly exceeding income amount to a withdrawal of resources from the company but are not components of income, and, therefore, are not dividends but represent the extraction of capital. Technical considerations supporting the revisions include the argument that the "non-operational" items in business-profits (removed by the COPC adjustment) are influenced by factors exogenous to the activity of corporations (such as exchange rate changes). Moreover, there is a 
lot of "noise" in changes in these items; thus, their deduction is likely to result in data more in line with the so-called "fundamentals." 13

In full acknowledgment of these considerations, in the next section we discuss some of the problems related to the perception, interpretation and comparability of the data resulting from alternative methodologies. Relying on simple numerical examples, we illustrate the effects of the methodological revisions on official statistics. The exercise intends to contribute to the clarification of an important question: did or did not the methodological changes meant to improve the quality of the data in a conceptual sense, also contribute to a better understanding of actual economic developments?

\subsection{The effect of alternative accounting methods on the perception and comparability of statistical data: numerical examples}

In what follows we consider the BoP and the IIP of three identical countries experiencing exactly the same FDI transactions, the only difference among them is that they record the transactions based on different accounting methods. The numerical examples are intended to highlight the problems of comparability entailed by the methodological revisions both over time and across countries. The first example illustrates some general issues related to the interpretation and comparability of the data; the second reflects specific features of the financial sector.

In our illustrative example, two FDI companies, $\mathrm{A}$ and $\mathrm{B}$, are assumed to operate in the country. Company A makes 100 units of after-tax profits according to its business accounts, this, however, includes 100 units of "non-operational" losses (e.g. due to exchange rate changes). The latter implies that its income, according to the COPconcept amounts to 200 units. Shareholders reinvest all of the profits; moreover, they invest additional 50 units of "fresh" capital in the company.

Company B makes zero profits; no "non-operational" items show up in its accounts; 50 units of dividends are paid to shareholders from the company' retained earnings. This implies that, according to the methodology that adjusts for SUD, all dividends of company B are accounted as SUD.

In a nutshell, there is a profitable FDI company, whose shareholders add 150 units to the net worth of their company, and there is another one, where the owners

\footnotetext{
${ }^{13}$ According to an analysis published by the Bank of England, the COPC adjustment had the following effect: "By excluding holding gains and losses, FDI income becomes much less volatile quarter on quarter. The remaining income streams tend to be quite stable over time and so we can expect MFIs' (monetary financial institution's) FDI income to fluctuate around the new level in the future." (Bowers-Farrell [2014] p. 8.) On the smaller volatility of adjusted profits see also Damgaard [2011]. However, in our view, the extent of volatility does not necessarily reflect the quality a time series.
} 
withdraw 50 units from the company's capital. At the macroeconomic level, the stock of direct investments in the country increased by 100 units. We might expect that this very simple story cannot be told in different ways. However, as demonstrated below, there may be three variants of the same story, depending on the statistical methodology applied.

Table 1 presents the basic information necessary for our comparisons.

Table 1

Transactions of FDI companies A and B - an illustrative example

\begin{tabular}{l|r|r|r}
\hline \multicolumn{1}{c|}{ Indicator } & Company A & Company B & Total economy \\
\hline After-tax profits (business accounts) & 100 & 0 & 100 \\
\hline Non-operational earnings (+) or losses (-) & -100 & 0 & -100 \\
\hline Income (COPC) & 200 & 0 & 200 \\
\hline Dividends & 0 & 50 & 50 \\
\hline of which: superdividends & & 50 & 50 \\
\hline After-tax profits minus dividends & 100 & -50 & 50 \\
\hline "Fresh" equity investment & 50 & 0 & 50 \\
\hline Total FDI investment & 150 & -50 & 100 \\
\hline
\end{tabular}

Note. Here and hereafter, COPC: current operating performance concept.

Let us now consider how the information presented in Table 1 is recorded in the BoP and the IIP of three countries applying three types of methodologies for accounting these transactions. (Alternatively, we may conceive of a single country, recording the same transactions at different points in time, while applying different methodologies.) In Table 2, the figures shown in column I correspond to the AIC, while those in column II reflect the COPC methodology of recording FDI profits in the BoP. Column III illustrates the accounts of a country applying the adjustment for both COPC and SUD.

In the first step, we compare the effects of the COPC adjustment with accounts based on the AIC of profits; in the second step, we review the additional effects of the adjustment for SUD. Our focus is on the influence of these methodological revisions on the measurement of FDI profits (income), RE, FDI flows, valuation effects and the change in the stock of FDI.

In our numerical example, as a result of the COPC adjustment, the size of income doubles, and RE trebles in the BoP (both increase by 100 units; compare rows 3 and 7 of columns I and II). The ratio of RE to income (the so-called "reinvestment ratio") accounted in the BoP increases from 50 to 75 percent (row 13). The current account 
deficit, along with the size of FDI inflows doubles (both increase by 100 units, see rows 8 and 9), while 100 units of revaluation and other losses (corresponding to nonoperational losses of FDI companies) are accounted in the IIP of the country applying the COPC adjustment (row 11 in column II). However, the change in net FDI assets (the inverse of inward FDI stocks), as shown by the IIP, is the same in the two countries applying different methodologies (see row 12).

Table 2

Illustrative scheme: the effect of three types of methodologies for accounting profits and dividends on the current and financial account of the BoP and the IIP

\begin{tabular}{|c|c|c|c|}
\hline Indicator & $\begin{array}{l}\text { I } \\
\text { AIC }\end{array}$ & $\begin{array}{l}\text { II } \\
\text { COPC }\end{array}$ & $\begin{array}{c}\text { III } \\
\text { COPC + SUD }\end{array}$ \\
\hline 1. After-tax profits (business accounts) & 100 & 100 & 100 \\
\hline 2. Non-operational earnings (+) or losses (-) & 0 & -100 & -100 \\
\hline 3. $(=1 .-2$.$) Operational earnings (profits)$ & 100 & 200 & 200 \\
\hline 4. Dividends (reported) & 50 & 50 & 50 \\
\hline 5. Superdividends & 0 & 0 & 50 \\
\hline 6. $(=4 .-5$.$) Dividends accounted in the BoP$ & 50 & 50 & 0 \\
\hline 7. $(=3 .-6$.$) Reinvested earnings$ & 50 & 150 & 200 \\
\hline 8. $(=(6 .+7) \times.(-1))$ Current account balance $($ BoP $)$ & -100 & -200 & -200 \\
\hline 9. (= 8.) Financial account balance (BoP, net assets) & -100 & -200 & -200 \\
\hline 10. Memo: Equity investment (in the financial account) & -50 & -50 & 0 \\
\hline $\begin{array}{l}\text { 11. }(=2 . \times(-1)) \text { Revaluation and other volume changes }(-) \\
\text { (IIP) }\end{array}$ & 0 & 100 & 100 \\
\hline 12. $(=9 .+11.) \Delta \mathrm{IIP}$ (change in net assets) & -100 & -100 & -100 \\
\hline $\begin{array}{l}\text { 13. (= 7. / 3.) Memo: Reinvested earnings / profits } \\
\text { (according to the BoP) }\end{array}$ & $50 \%$ & $75 \%$ & $100 \%$ \\
\hline $\begin{array}{l}\text { 14. (= (1. - 4.) / 1.) Memo: Unadjusted reinvested earn- } \\
\text { ings / unadjusted profits }\end{array}$ & $50 \%$ & $50 \%$ & $50 \%$ \\
\hline
\end{tabular}

Note. Here and hereafter, BoP: balance of payments; IIP: international investment position; AIC: allinclusive concept; SUD: superdividends.

Nevertheless, if we disregard the IIP and observe only the items displayed in the BoP, we are certain to get the false impression that, at least in terms of total FDI flows and RE, the country having adopted the COPC adjustment methodology is doing much better than the one applying the former methodology. Seemingly, the propensity of foreign owners to reinvest is significantly higher in the second (column II) than in the first country (column I). This perception lacks foundations, as shown by row 14, where the retained portion of the change in net worth is compared 
with the change in net worth itself: it is 50 percent in both countries, irrespective of the accounting regime. This ratio may be more relevant than the one conventionally considered (reinvestment ratio, see row 13).

The effects of the second methodological revision (SUD adjustment) are presented in column III of Table 2. As a result of this adjustment, the 50 units of reported dividends, considered as SUD, are deducted from the 50 units of equity capital inflow; therefore, both dividends and "fresh" FDI inflows turn to nil in the BoP (see rows 6 and 10). In addition, the adjustment increases RE by 50, to 200 units (row 7), and the "reinvestment ratio" (RE/profits in the BoP) reaches $100 \%$ (row 13). Our suggested indicator of the reinvestment rate, in turn, does not change (it remains at $50 \%$, see row 14).

Our numerical example is intended to demonstrate that, depending on the statistical methodology applied, the presentation and perception of the very same economic events can be profoundly different. Let us summarise some lessons of the example.

First, caution is warranted regarding the interpretation and comparison of profits, RE, FDI flows and, in particular, RE/profit ratios across countries applying different methodologies (as well as in a single country over time that has introduced methodological revisions). The revisions involve significant differences in the actual content of data having the same label; they may also result in large differences in their actual magnitude. They lead to breaks in the time series for these indicators.

Second, in countries applying the COPC adjustment, flows recorded in the BoP should be observed along with revaluation effects and other volume changes in the IIP. This is necessary because the COPC adjustment entails the allocation of important items (and essential information) from the business accounts of firms to the IIP, while other - equally important - items remain in the BoP. Users of FDI statistics should recognise that the IIP is not a dustbin but a major source of information.

Third, following the introduction of the COPC adjustment, besides net FDI flows, the change in the stock of net FDI should be monitored more closely, as the two may move quite differently. The change in the stock of FDI is a more comprehensive and relevant indicator than the one showing net flows.

Fourth, the SUD adjustment may be justified on conceptual grounds. However, it distorts perceptions regarding the capacity of a country both to attract and to keep foreign investors. As shown by our example, the country applying the SUD adjustment appears to be unable to attract "fresh" capital, while being able to keep every cent of profits made in the country. We know that, by our assumptions, this is a serious misperception of actual developments, but users of BoP statistics are likely get this impression. Except for Hungary, no information is internationally available on the size of SUD accounted as a withdrawal of equity.

Next, to illustrate the extent to which the methodological revisions can distort perceptions of actual developments, we construct a numerical example showing de- 
velopments in the foreign-owned financial sector of a country. The example may seem to be extreme, but it actually corresponds closely to the developments observed in Hungary in the period 2008-2014.

The point of departure is that profits in the foreign-owned financial sector are negative (according to the business accounts), but their losses related to revaluation effects and write-offs are even larger than their overall loss. Thus, according to the COPC interpretation of income, the sector actually makes profits. At the same time, the foreign owners are forced (by capital adequacy requirements) to recapitalise their banks, irrespective of the fact that the COPC adjustment suggests that their investments are profitable. Therefore, they invest "fresh" capital in their banks. In Table 3 a numerical example of these transactions is presented.

Table 3

Illustrative figures for the financial sector

\begin{tabular}{l|c}
\hline \multicolumn{1}{c|}{ Indicator } & Financial sector \\
\hline Profits (+) or losses (-) (business accounts) & -100 \\
\hline Non-operational earnings (+) or losses (-) & -200 \\
\hline Dividends & 0 \\
\hline Equity investment & 100 \\
\hline
\end{tabular}

There is an overall loss of 100 units, but the loss due to revaluation effects and write-offs contribute by 200 units to the loss. The decrease in capital of 100 units is made up by 100 units of equity capital inflow. The logical way of considering these transactions would seem to be that the 100 units of capital loss is cancelled out by the 100 units of equity investment; the net effect of these transactions should be nil. Let us now see, how these transactions are accounted by alternative statistical standards.

Accounting according to the AIC methodology:

$-\mathrm{RE}$ (profits - dividends): $(-100-0)=-100$

- Equity investment: +100

- Total FDI inflow $(\mathrm{RE}+$ equity $):(-100+100)=0$

- Revaluation effects: 0 .

Accounting according to the COPC methodology:

- Non-operational losses: -200

- Operational earnings (income) in the current account:

$[(-100-(-200)]=+100$ 
$-\operatorname{RE}(+100-0)=+100$

- Equity investment: +100

- Total FDI inflow: $100+\mathbf{1 0 0}=\mathbf{2 0 0}$

- Revaluation losses: 200.

$\triangle I I P$ (change in the stock of FDI):

- AIC methodology: 0 net transaction +0 revaluation $=\mathbf{0}$ change in stocks

- COPC methodology: +200 net transaction $+(-) 200$ revaluation effects $=0$ change in stocks.

As our example shows, in this case the AIC methodology presents a picture much closer to common sense than the COPC methodology. The former suggests zero net flow of capital, while the latter indicates that there was an inflow of 200 units. Moreover, data in line with the latter method (COPC adjustment), indicating an inflow of FDI, makes absolutely no sense without observing the accompanying loss accounted in the IIP. But how many analysts take the effort to look for the counterpart of the inflow recorded in the BoP among the valuation losses recorded in the IIP? Since very few do so, the general perception of users of COPC-adjusted FDI statistics is likely to be the following: the financial sector was so profitable that the foreign shareholders not only reinvested all their earnings but also increased the capital of their banks.

The example is intended to bring home an important message: the methodological changes have been introduced without any explicit warning regarding the increased relevance of items accounted in the IIP. To refer to our former metaphor: if important items are removed from the window to the warehouse of the statistical shop, users of the data need guidance regarding the interpretation of the changed content of the data. No such assistance is provided by the methodological manuals.

\section{Effects of the methodological changes on Hungary's statistics}

The following analysis aims to demonstrate the impact of the methodological revisions on Hungary's statistics on FDI flows, the composition of changes in FDI socks and, as an aside, on the country's current account. As an important part of this exercise, we show how the data between 2008 and 2014 would look like, if they were be based, as the time series up to 2007 are, on the unadjusted concept of profits and dividends. We consider it equally important to demonstrate that the methodologically revised data on FDI flows, presented in the BoP, should not be interpreted 
without considering valuation effects (and other volume changes) accounted in IIPstatistics. $^{14}$

The last year of the period covered by the analysis is generally $2014 .{ }^{15}$ Our quantitative analyses rely on the combination of official BoP data with the COPC and SUD adjustments reported in MNB publications.

\subsection{Effects of the methodological revisions on net FDI flows, $R E$ and changes in stocks}

We begin with demonstrating the overall impact of the methodological revisions on Hungary's FDI data from two perspectives. First, their effects on the measurement and interpretation of flows are considered; second, we show how alternative methodologies influence the perception of factors contributing to changes in stocks.

The two sides of Figure 1 show annual net FDI flows to Hungary in percentage of GDP between 1995 and 2014. The flows are decomposed into two major components: net RE on the one hand, and net "fresh capital" (equity plus debt instruments) on the other. The reason for focusing on net flows is that data on inflows and outflows excluding capital in transit (and restructuring of asset portfolios) is available only for the period beginning 2008. ${ }^{16}$ Net flows, by definition, are not influenced by the distortions affecting gross flows.

Figure $1 a$ ) shows net FDI inflows according to current official data. In the time series, there are two breaks (indicated by vertical lines): in 2008, when the COPC adjustment was introduced, and in 2013, the year since when the SUD adjustment has been applied. Figure $1 b$ ) until 2007 is identical to Figure $1 a$ ), but from 2008, data on RE is calculated according to the former methodology. The revision introduced in 2013 did not influence the size of net FDI flows; it only affected its composition (the share of "fresh" inflows decreased, while that of RE increased).

\footnotetext{
${ }^{14}$ By drawing attention to the importance of valuation effects, we follow the approach of those economists, who emphasize the significance of the "valuation channel" in the adjustment of global imbalances. See e.g. Ghironi-Lee-Rebucci [2009]; Gourinchas-Rey [2007]; Hausmann-Sturzenegger [2007]; Lane-Milesi-Feretti [2005], [2014].

${ }^{15}$ Developments in 2015 and 2016 are difficult to interpret and, more importantly, cannot be handled in our conceptual framework, emphasizing the equal importance of flows and other factors affecting changes in FDI stocks. As we do not wish to dwell on the statistical difficulties of handling two sides of an enormous and almost symmetrical, inward and outward transaction, we cover Hungary's experience only until 2014. MNB [2016], [2017b] provide some general information on these transactions.

${ }^{16}$ As explained by the methodological publication of the MNB: "Capital in transit are international enterprise group funds that pass through an economy to an affiliate in another economy, so that the funds do not affect the economy of that enterprise, but do not qualify as having special purpose due to their ownership structure. While these enterprises do engage in activity that is relevant to the Hungarian economy, these passthrough funds are not linked to developments or investments in Hungary and go to fund other operations, distorting the statistics on the components of direct investments." MNB [2014a] p. 3.
} 
a) According to the current methodology

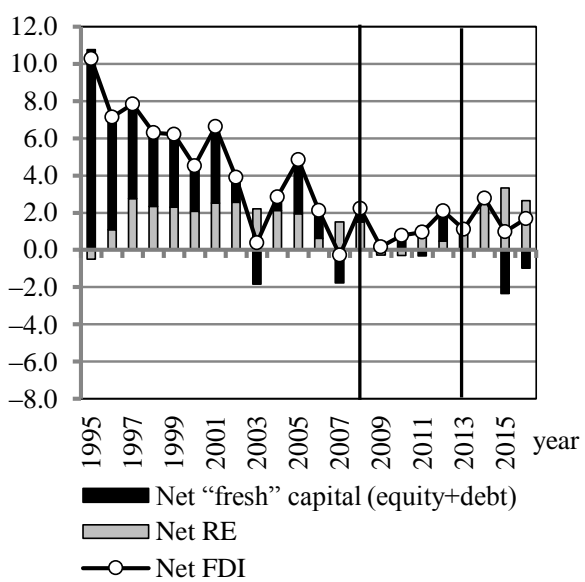

b) According to the methodology applied until 2007

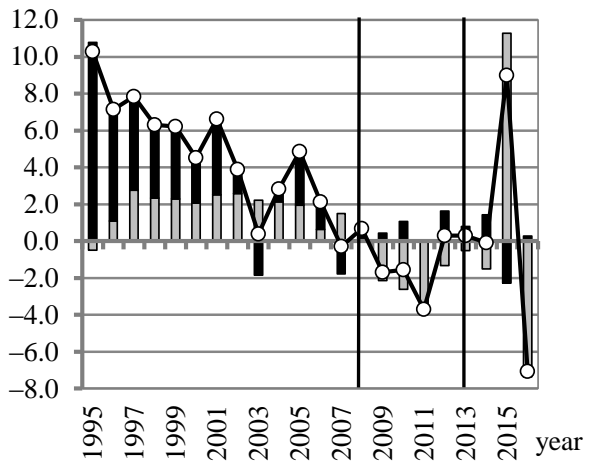

Net "fresh" capital (equity+debt)
- Net RE
$\longrightarrow$ Net FDI

Note. Here and hereafter, FDI: foreign direct investments; RE: reinvested earnings. Items with a positive sign reflect net inflows; negative values indicate net outflows.

Source: Own calculations based on BoP data of the MNB [2017c] and MNB publications referred to in footnote 3 .

As to the way in which Figure $1 b$ ) is constructed, the question may arise: why do we apply the former methodology forward, instead of using the present one backwards in time? The answer is simple: if the information necessary to reconstruct the earlier part of the time series according to the present method were available, the MNB would have already done so. Since such information does not exist, the only way of constructing a homogenous time series is the one shown by Figure $1 b$ ).

Figure 1 a), based on the current official data, shows that the net inflow of FDI has been increasing more or less steadily since 2009 , with a positive contribution of net RE (excluding two years, 2009 and 2010). Moreover, the chart actually suggests that by 2014, the ratio of net RE to GDP came close to the outstanding levels observed in the early 2000s. ${ }^{17}$ Overall, Figure $1 a$ ) gives the impression that, re-

${ }^{17}$ As put by the MNB's Report on the Balance of Payments published in 2015 September: "In 2014, the significant growth in foreign companies' profits... was primarily driven by an increase in reinvested earnings, the volume of which more than doubled over the past year. [...] That increase already pushed the profit generated by foreign companies to pre-crisis levels, accompanied by the rise of reinvested earnings to unprecedented levels." (MNB [2015b] pp. 28-29.) (Italics added by the author.) Only the last part of the text (implying the comparability of data on RE before and after 2008) is relevant from our point of view. The rest of the text involves a misunderstanding with respect to the casual relationship between profits and $\mathrm{RE}$ (see the discussion of formula /1/ in subsection 2.1). The quoted report was prepared by the economic analysts and not by the statisticians of the MNB. 
garding total net FDI flows and net RE, things are more or less on the right track in Hungary.

Figure $1 b$ ), however, based on comparable data, tells us a fundamentally different story. By applying the methodology followed until 2007, we can see that by 2014 the ratio of net FDI flows to GDP only reached the level already achieved in 2007. Between 2009 and 2011, there was a significant net outflow; between 2012 and 2014, net inflows were close to nil. This is explained by the fact that over the period 2008-2014, net RE, as calculated by the former methodology, was negative, while, based on the current methodology, it was continuously positive in each year, except for 2009 and 2010.

Figure 2 demonstrates the effect of alternative measurements of flows on the interpretation of how flows influence changes in stocks.

Figure 2. The stock of net FDI and the partial effect of cumulative net flows and other factors on the change in net FDI stocks, 2000-2016 (billion euros)

a) According to the current methodology

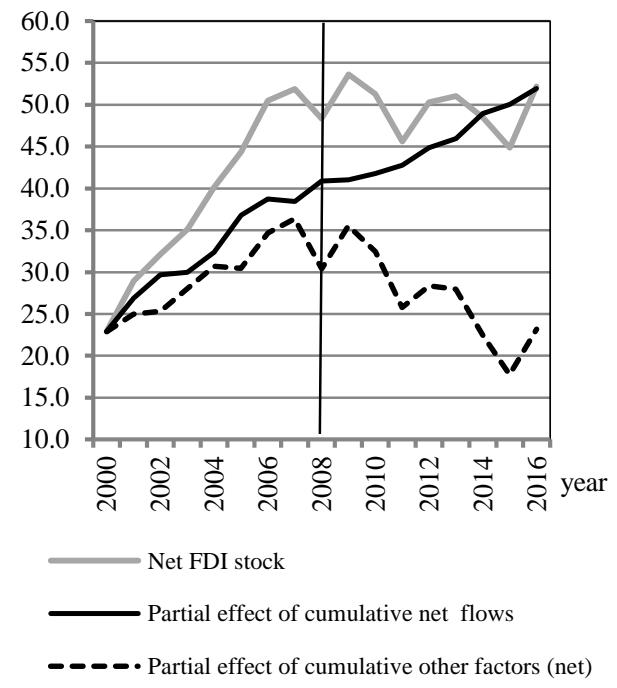

b) According to the methodology applied until 2007

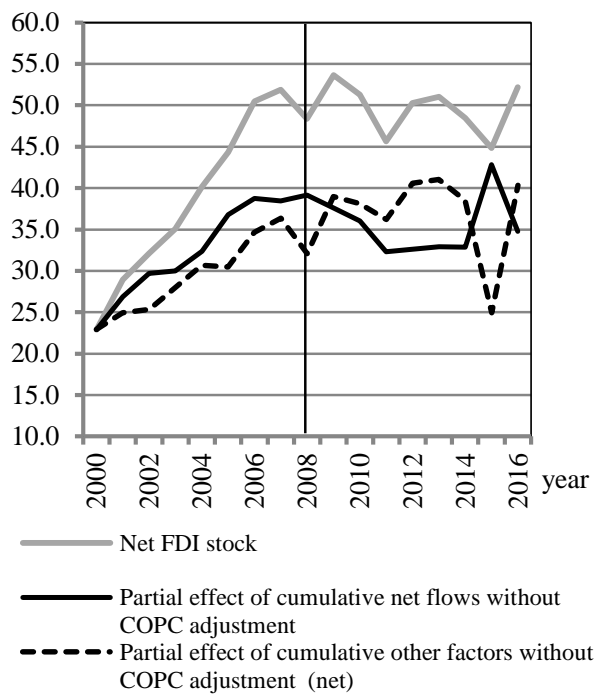

Source: Own calculations based on BoP data of the MNB [2017c].

The figure shows the partial contribution of cumulative net flows and other factors (valuation effects and other volume changes) respectively, to the stock of net FDI between 2000 and 2016. The grey line shows the actual level of net FDI stocks, while the black line indicates how the stock of net FDI would have evolved since 2000, if only cumulative net flows had contributed to the change in FDI stocks. The 
dashed line, in turn, shows the difference between the actual change in stocks and the cumulative partial contribution of flows. ${ }^{18}$

Here again, the chart on the left [Figure $2 a$ )] shows developments as depicted by the present methodology, while the chart on the right-hand side [Figure $2 b$ )] shows exactly the same developments, displayed according to the methodology applied until 2007.

Figure $2 a$ ) is helpful in explaining one of our initial paradoxes: why has the net stock of FDI not increased since 2008, if cumulative net FDI inflows were positive? As shown by Figure $2 a$ ), the partial contribution of net flows was positive and even increasing, but other factors (revaluation, etc.) had an increasingly negative partial effect. If it only depended on net flows, net FDI stocks would be much higher. The stagnating level of net FDI socks is due to huge losses related to other factors - according to the present official data.

Figure $2 b$ ) presents another version of the story. Applying the methodology used until 2007, there appears to be a clear downturn, rather than a continuous increase after 2008 in the contribution of FDI flows to changes in stocks. Following a sharp decline, stagnation can be observed until 2015, the year since which the difficulties of interpreting the data have emerged. According to the former methodology, there is neither any sign of an increase in the contribution of net FDI inflows, nor of a growing negative effect of revaluation and other losses. The two appear to cancel out each other (we later return to this observation).

Let us now turn to the aggregate effects of microeconomic developments. The following two figures show the details of how negative business profits can turn into income with a positive sign, and how business profits falling short of dividends can turn into reinvested earnings. ${ }^{19}$

The first of the three blocks of Figure 3 depicts foreign companies owned by Hungarians, the second provides information about foreign-owned Hungarian companies, and the third shows the net indicators interpreted as the difference between the latter and the former. In all of the three blocks, the first column represents aftertax business profits, the second shows non-operational earnings (COPC adjustment) and the third reflects income as accounted in the BoP. Consider the net indicators (the last three columns) consistent with the data presented in Figure 1. Between 2008 and 2014, cumulative net business profits amounted to 10 billion euros, but there was a net loss of 16 billion related to non-operational items (COPC correction), which

18 More formally, in year $t$, the partial effect of cumulative net flows is given by the formula PE_FDIflow $_{t}=$ FDI_stock $2000+\sum_{2000}^{t}$ FDIflow; and the partial cumulative effect of other factors is given by [FDI_stock $\mathrm{t}$-FDI_stock 2000$)$ - PE_FDIflow

${ }^{19}$ Here we deal with the cumulative effect of the COPC adjustment, but see $M N B$ [2017b] for an analysis based on annual data. 
was transferred to the IIP as revaluations and other volume changes. The difference between the first and second item, $[10-(-16)=] 26$ billion euros is the cumulative net income of FDI companies recorded in the current account of the BoP. According to the methodology applied until 2007, the cumulative net income would have been 10 billion euros during this period.

Figure 3. Indicators of Hungarian-owned foreign, foreign-owned Hungarian companies and net indicators: after-tax business profits, COPC adjustment and adjusted income, 2008-2014

(cumulative figures in billion euros)

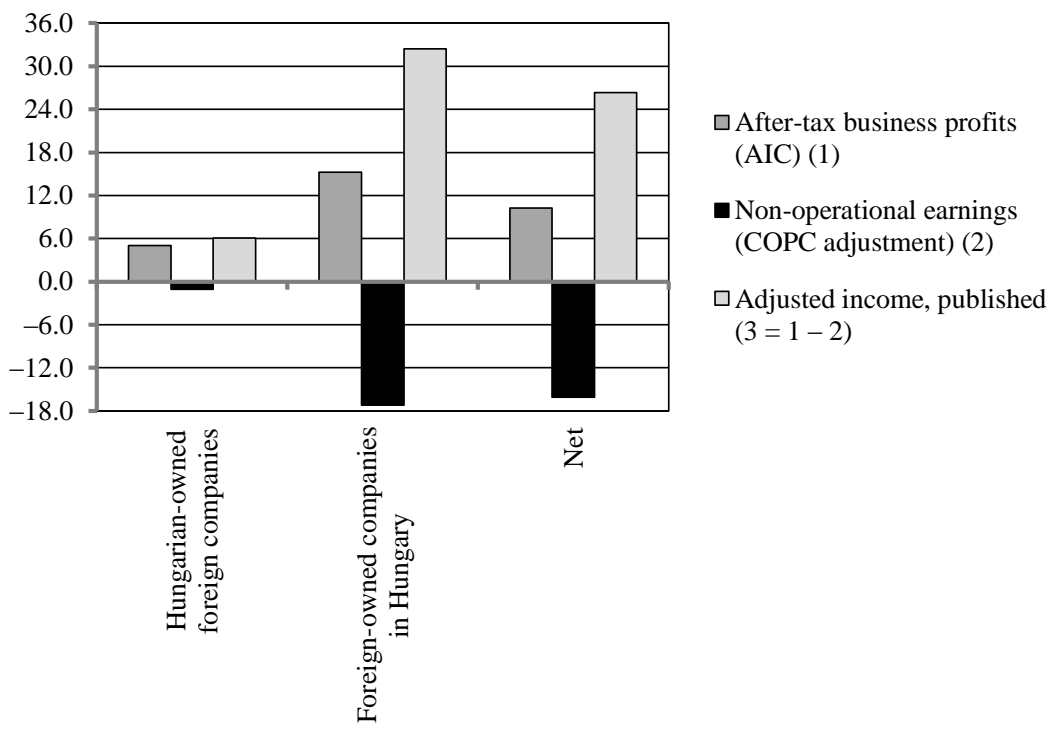

Note. Here and in Figure 4, "net" is understood as the difference between data for foreign-owned companies in Hungary and Hungarian-owned foreign companies.

Source: MNB [2014b], [2015a].

Figure 4 illustrates how the size of RE recorded between 2008 and 2014 was affected by the non-operational losses (COPC adjustment) and the SUD adjustment since 2013.

As shown by Figure 4, reported dividends significantly exceeded after-tax business profits, therefore the methodology applied until 2007 would have indicated a negative net RE of 11.5 billion euros in this period (i.e. withdrawal of resources, see the black bar on the right-hand side of the figure). However, due to the combined effect of the COPC and SUD adjustments, the cumulative net RE actually recorded in this period amounted to 6.7 billion euros (see the last bar on the chart). This is by 18.2 billion euros more than what would have been accounted according to the for- 
mer methodology. In our view, when trying to make a judgement on a country's "capacity to keep" investors, the information provided by both the former and the present methodologies should be taken into consideration - if both are available as in Hungary's case.

Figure 4. Indicators of Hungarian-owned foreign, foreign-owned Hungarian companies and net indicators: after-tax profits, dividends and the reinvested earnings calculated in three different ways, 2008-2014 (cumulative figures in billion euros)

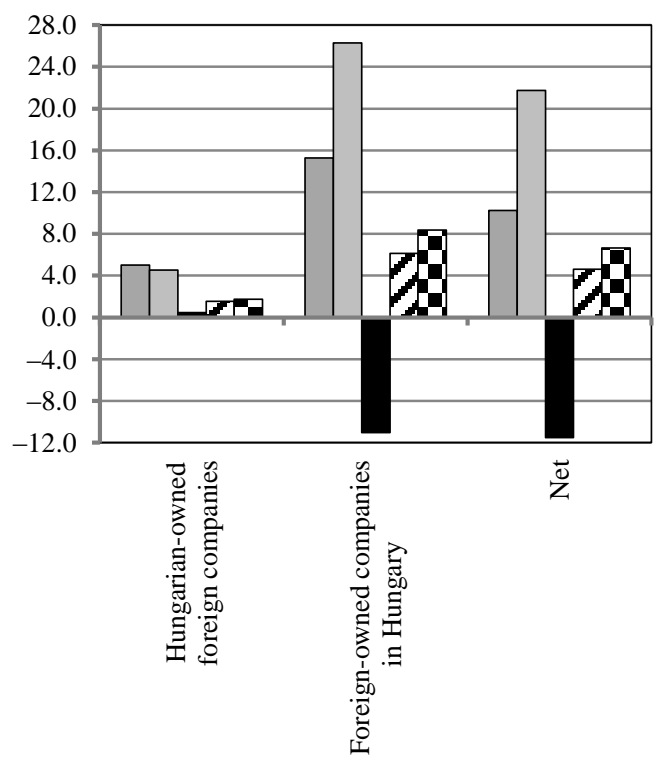

$\square$ After-tax business profits (AIC)

$\square$ Dividends

After-tax business profits less dividends (RE according to AIC)

$\square$ Adjusted income less dividends (RE until 2012)

- Adjusted income less adjusted dividends (RE since 2013)

Note. See Figure 3.

Source: Own calculations based on $M N B$ [2014b], [2015a].

The two charts of Figure 5 show time series for the ratio of net RE to GDP in two different ways. Figure 5 a) depicts official data (signalling the brakes by vertical lines), while Figure $5 \mathrm{~b}$ ) indicates the effects of the methodological revisions by showing how the figures would look like in the absence of these revisions.

The right-hand side of the figure clearly shows that the "fact" that net RE has been negative only in 2009 and 2010 is due to the first methodological revision. The other "fact" indicating a sharp upturn in RE after 2012, is the outcome of the second methodological revision. As shown by Figure $5 b$ ), both of the former methodologies would indicate a downturn; only the current methodology indicates an upturn in RE. 
Figure 5. The ratio of net RE to GDP in Hungary, 1995-2014 (percentage)

a) According to the official data

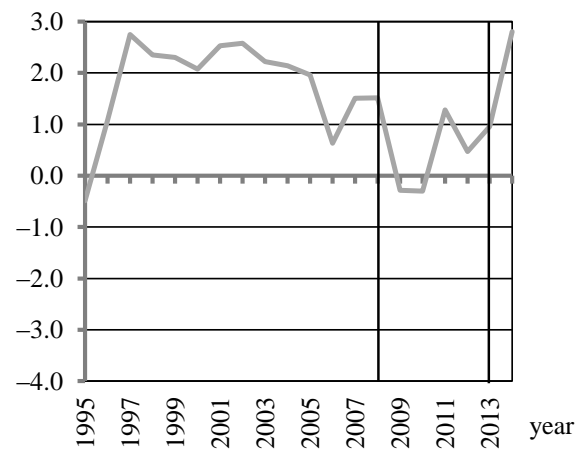

b) By indicating the breaks in time series

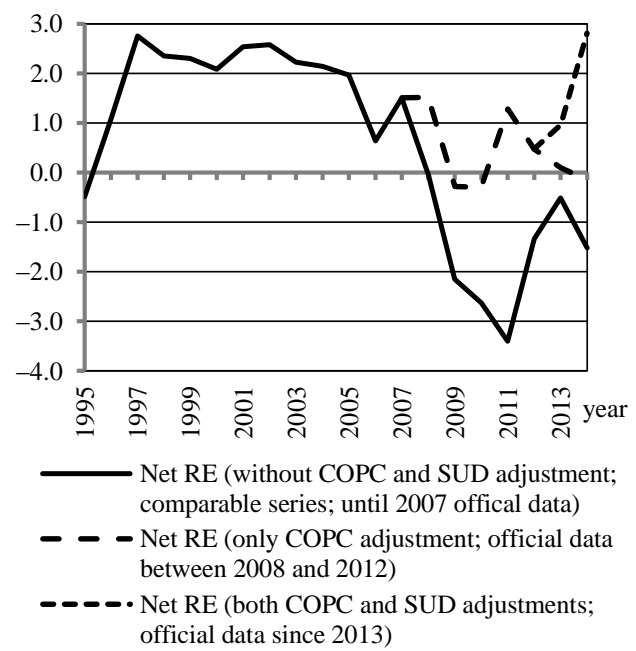

Source: Here and in the following figures and in Table 4, own calculations based on MNB-data.

\subsection{Sectoral contributions to the change in net FDI stocks, total returns on equity investments and alternative interpretations of the current account balance}

In this section, we first deal with the effect of the methodological revisions on factors contributing to changes in FDI stocks and on the sectoral composition of FDI flows. The information underlying our analysis is summarised in Table 4.

Focusing on differences between the financial and non-financial sector, we decompose the change in net FDI stocks between 2008 and the end of 2014 into cumulative flows and to the contribution of all other factors (revaluation and other volume changes). Flows are further decomposed into "fresh" capital (equity and debt) on the one hand, and RE, on the other. For both sectors, we separately indicate the size of the COPC and the SUD adjustment. Data corresponding to the current and the former methodology are presented in the first and the second column; the third column shows the difference between the two. Figures in the third column reveal the sources of the gaps between data based on alternative methodologies. The gaps related to total flows vs. other factors result from the COPC adjustment; the gaps within flows ("fresh" capital vs. RE), in turn, result from the SUD adjustment. 
Over the period under review, Hungary's stock of net FDI decreased by 1.2 billion (from 49.7 to 48.5 billion) euros. This change is the outcome of a decline of 3.2 billion euros in the financial sector (from 5.3 to 2.1 billion euros) and an increase of 2 billion euros in the non-financial sector (from 44.4 to 46.4 billion euros). The macroeconomic importance of these changes is shown by the following relative indicators: the ratio of total net FDI to GDP decreased from 48.6 to 45.9 percent; the corresponding changes for the financial and the non-financial sectors are: a decrease from 5.2 to 2.0 and an increase from 43.4 to 43.9 percent, respectively.

Table 4

Contributions to the change in the stock of net FDI in Hungary, 2008-2014 (for flows and revaluations, cumulative changes; in million euros)

\begin{tabular}{|c|c|c|c|}
\hline Indicator & $\begin{array}{c}\text { Current } \\
\text { methodology }\end{array}$ & $\begin{array}{l}\text { Former methodology } \\
\text { (without COPC and } \\
\text { SUD adjustments) }\end{array}$ & $\begin{array}{l}\text { Difference (cur- } \\
\text { rent minus former } \\
\text { methodology) }\end{array}$ \\
\hline \multicolumn{4}{|l|}{1 Total economy } \\
\hline 1.1 Net FDI flows & 10478 & -5608 & 16086 \\
\hline 1.1.1 "Fresh" capital & 3779 & 5898 & -2119 \\
\hline 1.1.2 RE & 6699 & -11506 & 18205 \\
\hline 1.1.3 Memo: SUD & 2119 & & \\
\hline 1.2 Valuation effects and other volume changes & -11693 & 4394 & -16086 \\
\hline 1.2.1 of which: COPC adjustment & -16086 & & \\
\hline 1.3 Change in FDI stocks (net liabilities) & -1215 & -1215 & 0 \\
\hline \multicolumn{4}{|l|}{2 Non-financial corporations } \\
\hline 2.1 Net FDI flows & 2707 & -5815 & 8522 \\
\hline 2.1.1 "Fresh" capital & -1256 & 579 & -1835 \\
\hline 2.1.2 RE & 3963 & -6394 & 10357 \\
\hline 2.1.3 Memo: SUD & 1835 & & \\
\hline 2.2 Valuation effects and other volume changes & -739 & 7784 & -8522 \\
\hline 2.2.1 of which: COPC adjustment & -8522 & & \\
\hline 2.3 Change in FDI stocks (net liabilities) & 1969 & 1969 & 0 \\
\hline \multicolumn{4}{|l|}{3 Financial corporations } \\
\hline 3.1 Net FDI flows & 7771 & 207 & 7564 \\
\hline 3.1.1 "Fresh" capital & 5035 & 5319 & -284 \\
\hline 3.1.2 RE & 2735 & -5113 & 7848 \\
\hline 3.1.3 Memo: SUD & 284 & & \\
\hline 3.2 Valuation effects and other volume changes & -10954 & -3390 & 7564 \\
\hline 3.2.1 of which: COPC adjustment & -7564 & & \\
\hline 3.3 Change in FDI stocks (net liabilities) & -3183 & -3183 & 0 \\
\hline
\end{tabular}


As shown by rows 1.3, 2.3 and 3.3 of Table 4, changes in stocks are invariant to the methodological revisions, so let us begin with comparing contributions to the change in stocks as measured by the current and the former methodology (applied until 2007) for the total economy (see rows 1.1. to 1.2.1). The current method indicates an impressive cumulative net FDI inflow of 10.5 billion, while the former one would show a disappointing picture: an outflow of 5.6 billion euros (row 1.1). The gap of 16.1 billion is solely due to the COPC adjustment (row 1.2.1), which, in Hungary's case, meant the removal of net non-operational losses from the business accounts. The SUD adjustment of 2.1 billion (row 1.1.3), in turn, simultaneously increased the size of RE (row 1.1.2) and decreased that of "fresh" capital (row 1.1.1), but did not affect total net flows. As a result of the two adjustments, the size of RE became by 18.2 billion euros larger than what it would be according to the former method. ${ }^{20}$

The table also demonstrates that the "principle of mass conservation" holds for the COPC adjustment: the losses removed from the BoP (and, by their deduction, having contributed to an increase in net inflows), reappear as revaluation and other losses in the IIP (contributing to a decrease in the net stock of FDI). Since the two sides of the COPC adjustment cancel out each other, the adjustment does not affect the change in net FDI stocks. It does, however, very powerfully affect perceptions. The former methodology would suggest a significant net outflow, primarily due to a large negative RE, only partly compensated by "fresh" inflows. The actual methodology, in contrast, indicates a huge net inflow, due to a EUR 6.7 billion net RE, amended by EUR 3.8 billion "fresh" capital.

As already emphasized in the foregoing, none of the two interpretations make sense in themselves. Both have to be complemented by observations on developments in valuation and other effects, accounted in the IIP (row 1.2). As shown in the table, according to the current methodology, valuation effects (and other changes) contributed by minus 11.7 billion euros to the change in net FDI stocks. But these effects would have been positive (4.4. billion euros), had the former methodology been applied (the difference between the two, 16.1 billion euros, corresponds to the COPC adjustment).

Our next question concerns the effects of the methodological revisions on the sectoral composition of net FDI flows. Figures corresponding to the present methodology (first column) indicate that cumulative net FDI flows received by the financial sector (7.8 billion euros, row 3.1.) were almost three times larger than flows to the non-financial sector (2.7 billion, row 2.1 ). This actually means that the financial sector (for easier exposition: the banks), with a share of 10 percent in total net FDI

\footnotetext{
${ }^{20}$ In the following, by an "increase" ("decrease") we mean that the value of an item is larger (smaller) according to the present methodology than what it would be according to the former method.
} 
stocks in 2008, account for three-quarters of total net FDI inflows between 2008 and 2014. Due to their dominant contribution to total net flows, the share of banks in total net FDI stocks should have increased markedly by 2014, but actually, the opposite happened: the share of the sector fell from 10 to 4 percent.

The explanation of this apparent paradox, just as in cases discussed previously, lies in the complementary side of transactions: valuation effects. If banks contributed in a disproportionally large extent to net inflows, their contribution to the negative valuation effects was even larger. The financial sector is "responsible" for roughly 95 percent of total losses due to valuation changes (cf. rows 3.2 and 1.2. in the first column) and, within the latter, for almost half of the total COPC adjustment (cf. rows 3.2 and 1.2 as well as 3.2.1 and 1.2.1 in the first column). The reason for the difference between the two ratios is that while valuation losses related to and unrelated to the COPC adjustment added up in the financial sector, reaching 11 billion euros (amounting to the double of the sector's net FDI stocks in 2008), the two practically cancelled out each other in the case of the non-financial sector.

How transactions and valuation effects in the financial sector would be accounted according to the former methodology (see rows from 3.1 to 3.2.1 in the second column)? First, net FDI flows received by banks would be close to zero (total net outflows would be associated with the non-financial sector). Second, reinvested earnings would be strongly negative (rather than positive, as suggested by the present method), expressing the fact that the financial sector ran huge losses in this period. Third, and most importantly, the size of "fresh" capital inflows would almost exactly correspond to the negative value of RE, clearly indicating that the motive for these inflows was the recapitalisation of foreign-owned banks by their shareholders, rather than the increasing "attractiveness" of the sector to foreign investors. Data corresponding to the current methodology may suggest the latter, which, to say the least, is a misunderstanding of actual developments.

In the non-financial sector, the revisions resulted in a significant increase in net FDI flows (row 2.1), however, as a result of their opposite impact on net valuation effects (row 2.2), they actually brought flows and changes in stocks closer to each other. This coincidence should not be considered as an indication that valuation effects can be disregarded; their profound effect is attested by developments in the financial sector.

Figure 6 confirms the importance of observing both transactions and valuation changes, but what really matters is the net effect of the components. The two sides of the figure show the composition of total returns on equity investments in Hungary as interpreted by the present [Figure $6 a$ )] and the former methodology [Figure $6 b$ )]. Total returns are broken down into profits and valuation and other effects, conforming to the two methods. Though the actual size and contribution of the two components depend on the methodology, their net effect is the same. While the present method, in contrast with the former one, suggests that the rate of profit was relatively stable during the period 
observed, the total rate of return is characterised by wide fluctuations, irrespective of the chosen methodology. This, again, supports our argument that the net effect, uninterrupted by the methodological changes, is the relevant indicator to be observed.

Figure 6. The composition of total returns on equity assets invested in Hungary, 2008-2014 (percentage)

a) According to the current methodology

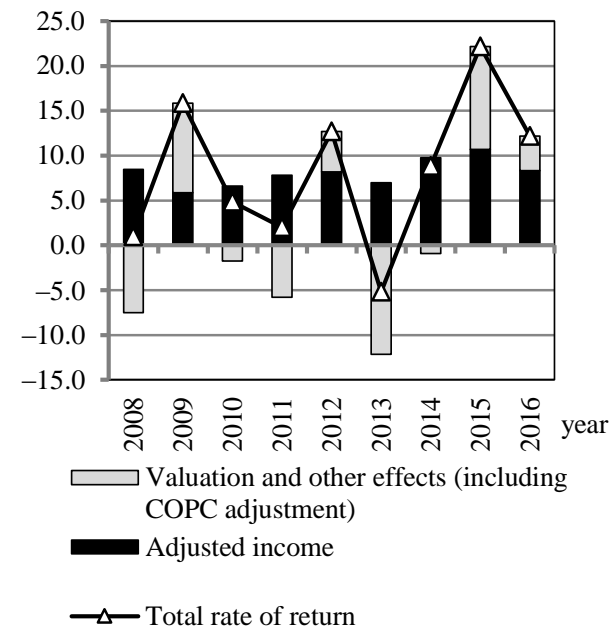

b) According to the former methodology

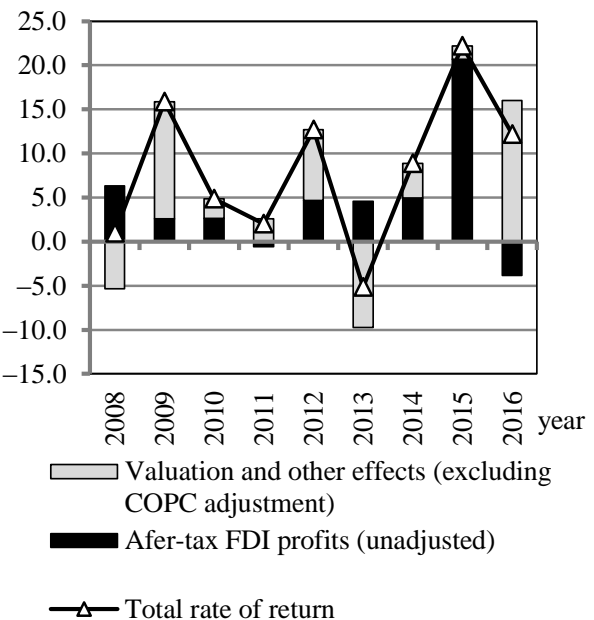

As a final point, we show the "reverse side" of the methodological revision introduced in 2008. The COPC adjustment increased net RE in (i.e. net FDI flows to) Hungary (as compared with the unadjusted figures), accounted in the financial account of the BoP. However, at the same time and in the same magnitude, it also increased FDI income of non-residents, accounted in the current account of the BoP. The latter, in turn, resulted in the deterioration of the current account (again, as compared with the unadjusted data).

In countries having large external imbalances, coupled with high foreign debt (a constellation having characterised Hungary in 2007-2008), the balance of the current account is perhaps the most closely monitored indicator. Investors, credit rating agencies and market analysts often make judgements on the prospects of an indebted country on the basis of developments in the current account. This information is essential also for macroeconomists studying e.g. international experiences of external adjustment of countries. However, as shown by Figure 7, users of the data on Hungary's current account are mistaken if they consider the figures to form a homogenous time series. ${ }^{21}$

${ }^{21}$ In a Hungarian article on Hungary's external adjustment (Halpern-Oblath [2014]), we have made this mistake. We have ignored the effects of the methodological revisions, since, at the time of writing, we were unaware of their existence. 
Figure 7. The effect of the COPC adjustment on the current account of Hungary's BoP, 1995-2014 (in percentage of GDP)

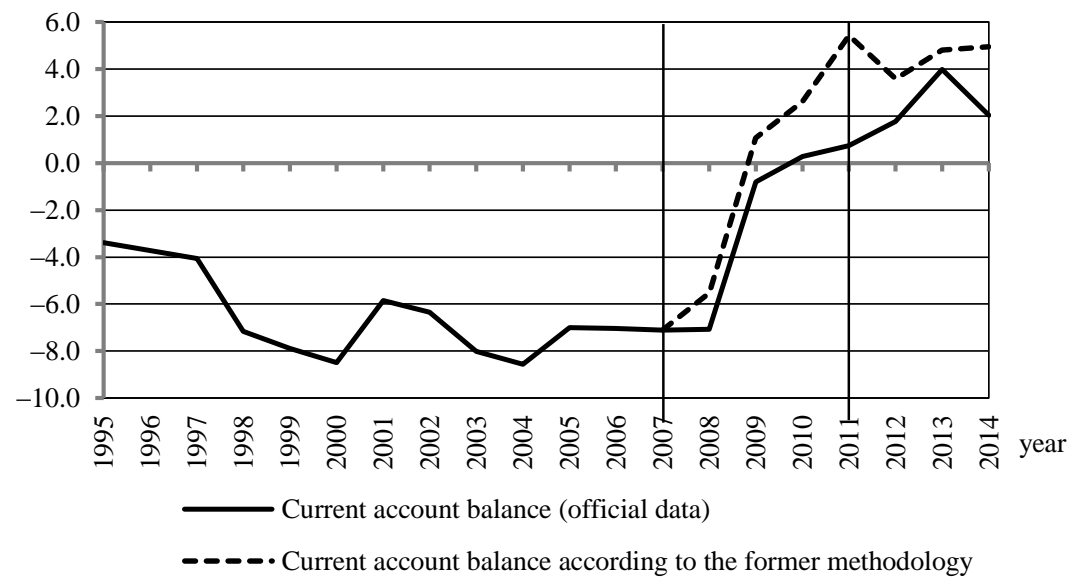

The continuous line in Figure 7 shows the official data on the current account balance, the dashed line, in turn, illustrates how the balance would look like if the methodology used until 2007 was applied for latter years as well; both series show data relative to GDP. Actually, only the combination of the continuous line until 2007 and the dashed line since 2008 can be considered as a homogenous series, based on the same accounting principles.

It can clearly be seen that the methodological revision introduced in 2008 had a significant influence on the measured size of external adjustment between 2007 and 2011. The official data indicate an adjustment of 8 percent, while the former methodology suggests a 12.5 percent change relative to GDP. The unsuspecting users of official statistics, unaware of the gap of 4.5 percentage points, are certain to underrate both the speed and the extent of the adjustment in Hungary's current account balance after 2007 .

\section{Summary and conclusions}

Our study examined two, internationally endorsed methodological revisions, which affect the measurement and interpretation of FDI flows. The modifications concern the quantification of FDI profits and dividends, and thus, the difference between the two, i.e. RE of FDI companies. RE in a country is accounted as an FDI flow to the country. 
The rationale underlying the revisions was to bring closer the empirical indicators of profits and dividends to their conceptual counterparts. While not questioning this endeavour, our study drew attention to certain important implications of the methodological changes.

First and most importantly, they resulted in breaks in the time series for several significant macroeconomic indicators, including the balance and the composition of the current and the financial account of the balance of payments (BoP). Most users of these statistics are unaware of the timing and empirical importance of the breaks in the series, the more so, since Hungary seems to be the only country disclosing the information necessary for reconstructing comparable time series for the respective indicators.

Second, the revisions have led to an increased uncertainty in international comparisons. Since very little is known about when actually and to what extent did countries introduce the methodological changes, the comparability of data on FDI flows, profits and RE is in doubt. ${ }^{22}$

Third, even if the adjusted data correspond more closely to the respective statistical concepts, they may misrepresent the actual intentions and decisions of foreign shareholders. As shown by data on Hungary, foreign investors have collectively decided on much larger total dividends than total after-tax profits. While this actually means a withdrawal of resources from their companies, the adjusted data suggests exactly the opposite, namely, that the owners have, to a large extent, reinvested their profits. Therefore, the conceptually superior data on RE should by no means be interpreted as reflecting the collective behaviour or foreign shareholders.

The other main message of our study relates to the importance of information hidden in statistics on the IIP of countries. Following the introduction of the methodological revisions, the significance of these statistics increased, as items removed from the books of FDI companies can be retrieved in the IIP, among valuation effects and other changes in capital. The data presented in the BoP should be interpreted in view of these changes. This also means that we consider the change in net worth (the change in net FDI stocks) as a better representation of developments related to FDI than the flow data displayed in the BoP.

Finally, a greater transparency of national FDI data with respect to the timing and quantitative impact of the methodological revisions reviewed in our study is essential for the interpretation and international comparability of FDI statistics. International organisations having endorsed these methodological revisions should also take the initiative to ensure that the respective data do actually become more comparable. They could do this by requesting national agencies to disclose, simi-

\footnotetext{
${ }^{22}$ The OECD metadata database provides information on member countries having applied the COPC adjustment in 2016, but it does not indicate the year when this revision was introduced or the fact whether or not the SUD adjustment is also applied. See https://qdd.oecd.org/subject.aspx?Subject=fdi_metadata
} 
larly to the MNB, information on the timing of the methodological changes, as well as on the magnitude of the revisions. This could contribute to the comparability of data on FDI flows and, thus, assist economists drawing on these data in their analyses.

\section{References}

Bowers, L. - FARrell, K. [2014]: Revisions to UK GDP and the Balance of Payments Current Account Sourced from the Bank of England. Bank of England. London. http://www.bankofengland.co.uk/statistics/Documents/ms/articles/art3sep14.pdf

DAMGAARD, J. [2011]: Measuring FDI and Its Impact on the Danish Economy. University of Southern Denmark. http://www.nationalbanken.dk/en/publications/Pages/2011/08/MeasuringFDI-and-Its-Impact-on-the-Danish-Economy.aspx

Ghironi, F. - LeE, J. - Rebucci, A. [2009]: The Valuation Channel of External Adjustment. IMF Working Papers WP/09/275. http://www.imf.org/en/Publications/WP/Issues/2016/12/31/TheValuation-Channel-of-External-Adjustment-23447

Gourinchas, P.-O. - ReY, H. [2007]: International financial adjustment. Journal of Political Economy. Vol. 115. No. 4. pp. 665-703. http://dx.doi.org/10.1086/521966

HalPeRn, L. - Oblath, G. [2014]: A gazdagsági stagnálás „színe” és fonákja. Közgazdasági Szemle. Vol. LXI. Nos. 7-8. pp. 757-800.

Hausmann, R. - Sturzenegger, F. [2007]: The missing dark matter in the wealth of nations and its implications for global imbalances. Economic Policy. Vol. 22. Issue 7. pp. 470-518. http://dx.doi.org/10.1111/j.1468-0327.2007.00182.x

IMF (InTERnational Monetary Fund) [2009]: Balance of Payments and International Investment Position Manual - Sixth Edition (BPM6). Washington, D.C. https://www.imf.org/external/pubs/ft/bop/2007/bopman6.htm

Lane, Ph. R. - Milesi-Ferretti, G. M. [2005]: A Global Perspective on External Positions. IMF Discussion Papers No. 79. June. http://dx.doi.org/10.2139/ssrn.922009

Lane, Ph. R. - Milesi-Ferretti, G. M. [2014]: Global imbalances and external adjustment after the crisis. IMF Working Papers. Vol. 14. Issue 151. August. http://dx.doi.org/10.5089/9781498339216.001

MNB (Magyar Nemzeti Bank, THE CENTRal bank of Hungary) [2014a]: Methodology for the Compilation of Balance of Payments and International Investment Position Statistics - BPM6 (from June 2014). http://www.mnb.hu/letoltes/bop-meth-notes-bpm6-en.pdf

MNB [2014b]: Press Release. Hungary's Balance of Payments: 2014 Q2. 23 September. http://www.mnb.hu/letoltes/bpm6-press-2014-q2-en.pdf

MNB [2015a]: Press Release. Hungary's Balance of Payments: 2015 Q2. 23 September. http://www.mnb.hu/letoltes/bpm6-sajtokozlemeny-2015-q2-en.pdf

MNB [2015b]: Report on the Balance of Payments. September. https://www.mnb.hu/ letoltes/fizetesi-merleg-jelentes-2015-q2-en.pdf

MNB [2016]: Press Release. Hungary's Balance of Payments: Q2. September. http://www.mnb.hu/letoltes/bpm6-sajtokozlemeny-2016-q2-en-final.pdf 
MNB [2017a]: Report on the Balance of Payments. July. http://www.mnb.hu/en/ publications/reports/report-on-the-balance-of-payments/report-on-the-balance-of-paymentsjuly-2017

MNB [2017b]: Press Release. Hungary's Balance of Payments: 2017 Q2. 20 September. http://www.mnb.hu/letoltes/bpm6-sajtokozlemeny-2017-q2-en-jav.pdf

MNB [2017c]: Data According to the BPM6 Methodology. Balance of Payments, International Investment Position. https://www.mnb.hu/en/statistics/statistical-data-and-information/ statistical-time-series/viii-balance-of-payments-foreign-direct-investment-internationalinvestment-position/balance-of-payments-international-investment-position/data-according-tobpm6-methodology

OECD (ORganisation For ECONOMiC Co-OPERATION AND DEVElopment) [2008]: OECD Benchmark Definition of Foreign Direct Investment. Fourth Edition. https://www.oecd.org /daf/inv/investmentstatisticsandanalysis/40193734.pdf 